\title{
座標変換に基づく情報ハイディング手法
}

新井 康平 9 (佐賀大学), 瀬戸 要 (株式会社サインズ)

\section{Information hiding method based on coordinate transformation}

\author{
Kohei Arai, and Kaname Seto
}

\begin{abstract}
A method for image hiding based on Multi-Resolution Analysis(MRA) with image cordinate transformation as a preprocessing is proposed. The method allows hide key images in the most efficient manner in terms of invisibility of the key images as well as information content point of view. Such efficiency is shown with the experimental images.
\end{abstract}

Keywords: Multi-Resolution Analysis, Multi-band imagery data, Coordinate transformation

\section{1 まえがき}

情報ハイディングは透かし技術やステガノグラフィ 技術の総称であり、外に表机た情報は原デー夕（原画 像）と呼ばれ、外には表れない情報は秘密データと呼 ばれる。情報ハイディング手法 1 1),2),3\} は、

・原画像の害空間上において秘密デー夕を埋め込 む手法 4 )

- 原画像の周波数空間上において秘密デー夕を埋 め込む手法 5),6)

に大別できる。埋め込み後の流通用画像に対して圧縮 等の処理を施されても原画像の比較的影響を受けにく い特定の周波数帯に秘密デー夕を埋め込むことが可能 であるという観点から、前者に比べ後者は秘密デー夕 の情報を隠蔽する能力がある。前者は、原画像のエッ ジ部分等を操作して秘密デー夕を埋め込む工夫が必要 となる 4)。後者は、秘密デー夕を埋込むべき原画像 の周波数带の決定が必要となる57,6)。また, R,GB・カ ラーの原画像を用いた情報ハイディング手法も提案さ れている7),8）。原画像の情報量の観点から、カラ一原 画像を用いた情報ハイディングは、非カラー原画像を 用いた情報ハイディングに比べ秘密データの情報を隠 蔽する能力がある。カラーの原画像を用いた情報八イ ディングは、原画像のある成分に対して秘密デー夕を 埋め込む手法が用いられる。例えば、原画像の G 成 分に秘密デー夕を埋め込む手法が採用される3)。した がって，原画像の G 成分に秘密データを埋め込む場台、 原画像の R. 成分および $\mathrm{B}$ 成分の情報は使用しないこ とになる。

本論文では，原画像である多バンド画像のいずれか のバンド画像に秘密デー夕を埋め込む手法の欠点を克 服する目的のため、主成分変換および座標変換を伴う 多重解像度解析に基づく多バンド画像を用いた情報ハ イディングを提案し、その提案手法の有效性を確認し たので報告する。

\section{2 直交座標表現と斜交座標表現}

2次元空間における、直交座標表現と斜交座標表現 とは

$$
\left\{\begin{array}{l}
W=X+Y \cos (\theta) \\
Z=Y \sin (\theta)
\end{array}\right.
$$

という関係がある。

\section{3 提案手法}

2 次元信号に対してウェーブレット分解を行なうと 4 成分 11 低周波成分（LL1 成分）亡 3 高周波成分 (LH1 成分・HL1 成分・HH1 成分)]が生成される。 また、LL1 成分に対してウエーブレット分解を行なう 之 4 成分 ( LL2 成分 · LH2 成分 · HL2 成分 · HH2 成 分）がさらに生成される。双直交ウェーブレットを採 用し、かつ、ウェーブレット分解後の 4 成分が存在す れば、誤差零で与えられた 2 次元信号は復元される。 直交ウェーブレットは、双直交ウェーブレットの 1 種 である。すなわち、双直交ウェーブレット変換㹥逆変 換可能である。

多重解像度解析に基づく情報ハイディング手法の概 要を示す。情報ハイディングは、

1. 多バンド原画像のいずれかのバシド画像に対し てウェーブレット分解を行う

2. ウェーブレット分解後の高周波成分に秘密デー 夕を挿入する

3. ウェーブレット再構成により流通用画像を生成 する

の手順で行われる。秘密デー夕を HL1 成分や HH1 成分や HH2 成分等に挿入することも可能である。秘 密デー夕を挿入する成分が変更可能であるということ は、多重解像度解析に基づく情報ハイディングが秘密 データの情報を保護する能力があるということである。 
ここで問題となるのが、情報ハイディングの手順 1 の 「多バンド原画像のいずれかのバンド画像に対して」と いう点である。提案手法は、多バンド原画像のエネル ギー集中を実現する前処理として主成分変換が用いら れ、秘密デー夕を第 1 主成分画像にハイディングする。 主成分変換は直交変換の 1 種であり、逆変換可能であ る。また、提案手法は、3 バンドの原画像ではない場 合にも適用可能である。換言すると、提案手法は八イ ディングによる画質劣化を抑えることを目的として、 多バンド原画像に対して主成分変換を行い、その第 1 主成分画像に秘密デー夕をハイディングする。その際、 斜交座標変換を行う。さらに、秘密デー夕の復号法を 説明する。秘密データがハイディングされる前の多バ ンド原画像に主成分変換を行った際の係数を用いて、 流通用画像に対して第 1 主成分画像を構成し、その第 1 主成分画像に対してウェーブレット分解を行うこと により実現される。提案手法による秘密デー夕の復号 は、鍵画像情報を八イディングする前の多バンド原画 像に主成分変換を行った際の係数を知っている場合の み復号可能である。すなわち、秘密デー夕をハイディ ングする前の多バンド原画像により、主成分変換の倸 数は異なる。HSI 変換等の係数は, 周知のものである。 変換係数が周知である場合、第 3 者が秘密デー夕の情 報を入手する可能性がある。

\section{4 数值実験}

\section{1 使用データ}

本論文での使用デー夕は、図 1 を原デー夕(多重分 光画像) とし、図 2 を秘密デー夕とする。すなわち、 図 2 のデー夕を図 1 のデー夕にハイディングするこ とを行う。図 3 〜図 5 は、図 1 の各波長帯域のデー 夕である。図 5 より、図 1 の B 成分は全て零である ことがわかる。図 6 は、図 1 の R 成分と $\mathrm{G}$ 成分の散 布を示す。図 7 は、図 6 に対して主成分変換を行っ た結果である。図 7 の縦軸は第 1 主成分軸であり、図 7 の横軸は第 2 主成分軸である。

\section{2 実験方法}

図 8 は、図 7 の散布をパラメータ $\theta$ により斜交座 標変換を施した結果例である。図 9 は、図 8 (b) に 秘密デー夕をハイディングを行った結果である。すな わち、第 3 者は図 9 から秘密デー夕を推定することに なる。本実験の目的は、パラメー夕 $\theta$ により秘密デー 夕の保護が向上することを示すことである。したがっ て、図 9 の第 1 主成分画像からウェーブレット変換を 用いて秘密デー夕を推定することを試みる。なお、第 3 者は、原デー夕の情報を知らないものとし、ウェー ブレット基底および秘密デー夕を埋め込んだ成分（例 えば、HH1 成分）の情報をなんらかの方法で知り得 たものとする。すなわち、当事者が保有する固有べク トル等の情報とパラメータ $\theta$ を第 3 者は未知とする。

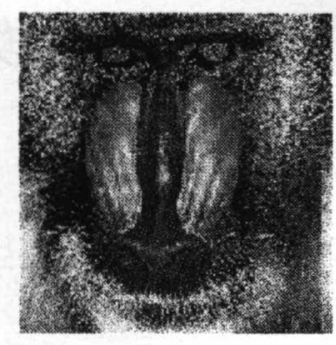

図 1: RGB カラー原データ

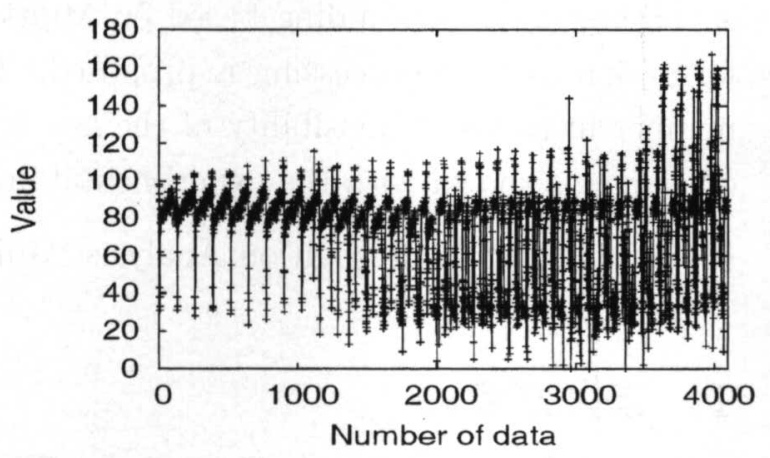

図 2: 秘密データ

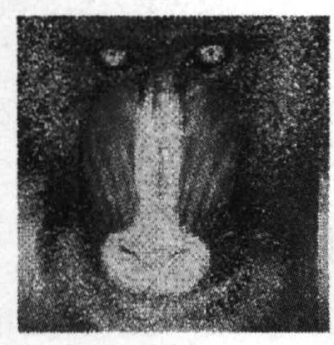

図 3: RGB カラー原データの R 成分

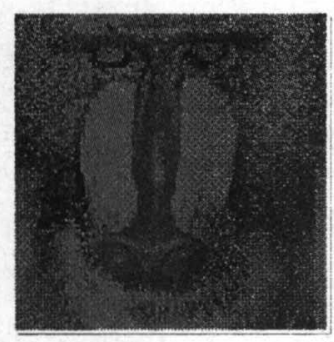

図 4: RGB カラー原データの $\mathrm{G}$ 成分

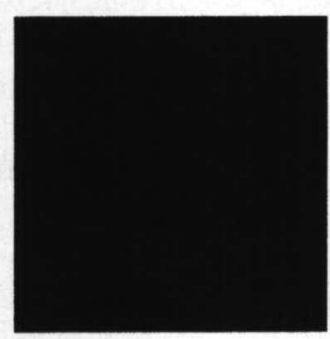

図 5: RGB カラー原データの B 成分 


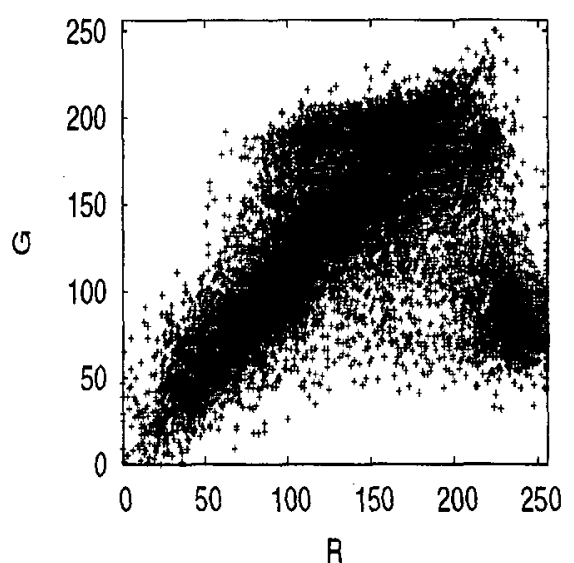

図 6: RGB カラー原データの $\mathrm{R}$ 成分と $\mathrm{G}$ 成分の 散布

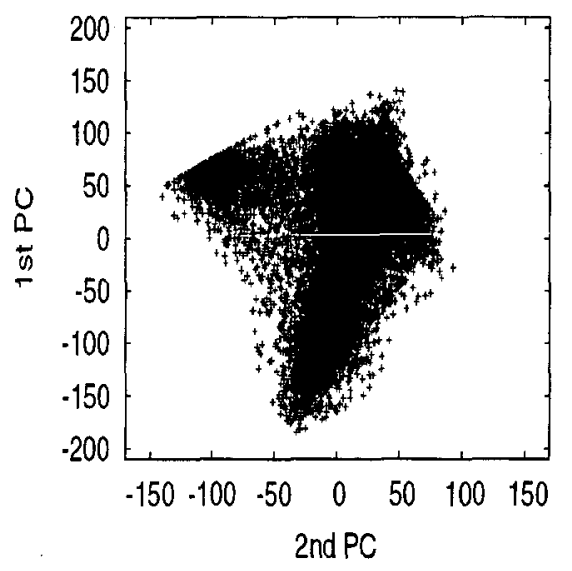

図 7: RGB カラー原データの R 成分と $\mathrm{G}$ 成分の 散布の主成分変換の結果

図 6 の散布から図 7 の散布に変換を行うための平 均ベクトルは、

$$
\left(\begin{array}{ll}
137.7724 & 129.2966
\end{array}\right)
$$

であり、変換係数は

$$
\left(\begin{array}{l}
\xi_{1}^{T} \\
\xi_{2}^{T}
\end{array}\right)=\left(\begin{array}{cc}
0.8353 & 0.5496 \\
-0.5496 & 0.8353
\end{array}\right)
$$

である。ただし、 $\xi_{1}$ は第 1 固有ベクトルであり、 $\xi_{2}$ は 第 2 固有ベクトルである。図 6 の散布から図 7 の散 布に変換を行うための情報は、当事者のみが知り得る ものである。

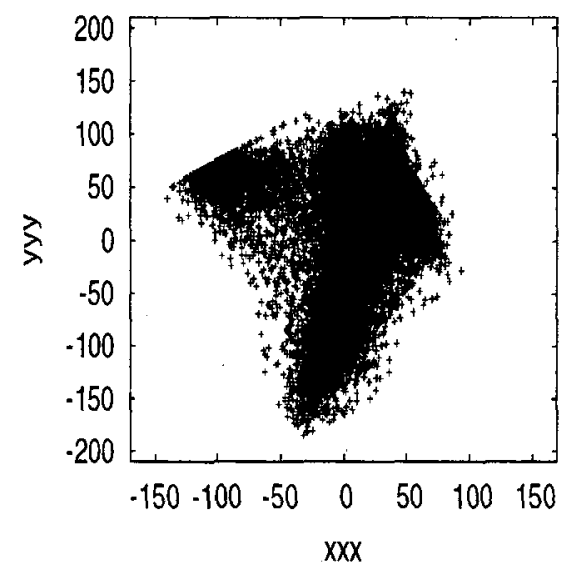

(a) $\theta=90^{\circ}$

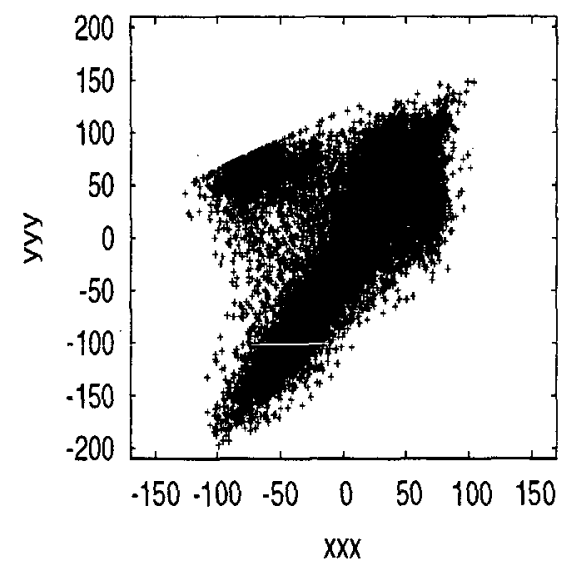

(b) $\theta=110^{\circ}$

図 8: 斜交座標変換後の散布の例 $\left(\theta=90^{\circ}, 110^{\circ}\right)$

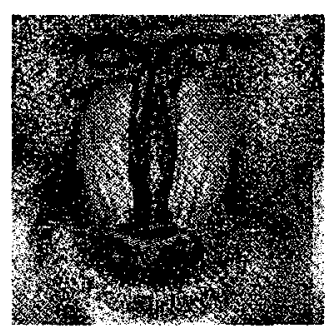

図 9: 流通用データの例 $\left(\theta=110^{\circ}\right)$

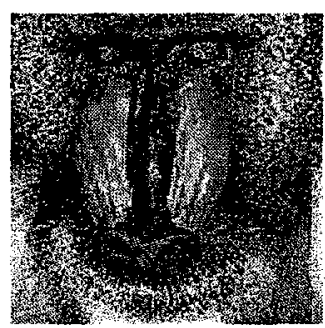

図 10: RGB カラー原データ 


\section{3 実験結果}

パラメータ $\theta$ を変化させて秘密デー夕を埋め込ん だそれぞれの流通用データに対して、第 3 者が秘密 データを流通用デ一タから推定することを試みた場合 の RMS 誤差を図 11 に示す。

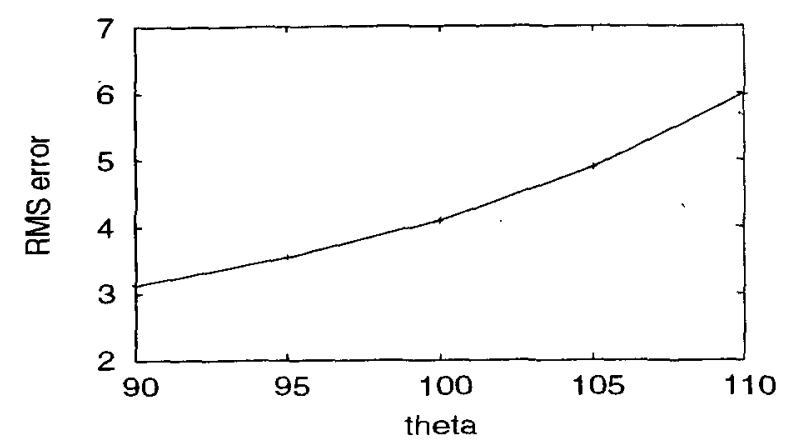

図 11: パラメータ $\theta$ に対する RMS 誤差

\section{5 考察}

図 11 より、第 3 者が秘密デー夕を流通用デー夕か ら推定することを試みた場合の RMS 誤差はバラメー 夕 $\theta$ に依存することがわかる。すなわち、パラメー 夕 $\theta$ により秘密データの保護が向上することがわか る。また、原データの情報を保護することにより、秘 密データの保謢が可能となることがわかる。

\section{6 あとがき}

本論文では、多重分光画像を用いた情報ハイディン グ手法について検討した。すなわち、第 3 者が流通用 データのみから秘密データを抽出することを試みた場 合の検討を行った。本提案手法は、原デー夕となる多 重分光画像の特性を知る当事者のみが秘密デー夕を復 元できるものである。すなわち、原データの情報を保 護する必要がある。さらに、提案手法においては、固有 ベクトルの存在および斜交座標変換により、秘密デー 夕の情報を保謢する。すなわち、少なくとも真の原画 像の情報を知らなければ、秘密情報を復元できない。 主成分変換の係数は、原デー夕毎に異なり、原データ の固有ベクトルにより構成される。3バンド・カラー 画像においては、HSI 変換等を伴う手法も考えられ るが、HSI 変換等の変換係数は周知の係数である。秘 密情報の保護の観点から、提案手法の有効性を確認し た。本論文では、ウェーブレットとして Daubechies 基底を採用したが、双直交ウェーブレットであれ格秘 密情報を復元できる。双直交ウェーブレットとして何 を採用するかを隠蔽することによっても秘密デー夕を 保護することができると考える。

\section{参考文献}

（1）松井甲子雄：“電子透かしの基礎,"㷊北出版，(2000).

[2] 川合淳郎：“透加し一本物の証・紙のすき入れ（透かし）-," 画像電子学会諘, Vol. 31, No. 2, (2002), pp.253-260.

[3] 河口英二・野田秀樹・新見道治：“ディジタル・ステガノグラ フィ技術について,”画像電子学会誌, Vol. 31, No. 3, (2002), pp.414-420.

[4] 岡本晃宏・宮崎明雄：“モルフォロジカル信号処理を利用し た電子透玑し方式,”電子情報通信学会論文誌 A, Vol, J84-A， No. 8, (2001), pp.1037-1044.

[5] I. J. Cox, J. Killian, T. Leighton, and T. Shamoon : "Secure Spread Spectrum Watermarking for Multimedia," IEEE Trans. Image Process., Vol. 6, No. 12, (1997), pp.1673-1687.

[6] 井上尚・宮崎明雄・島津幹夫・桂卓史：“ウェープレット変換 を朋いた画像信号に関する電子透かし方式,"映像情報入ディ ア学会誌, Vol. 52, No. 12, (1998), pp.1832-1839.

[7] R. Ouellette, H. Noda, M. Niimi, and E. Kawaguchi: "Topological Ordered Color Table for BPCS Steganography Using Indexed Color Images," IPSJ Journal, Vol. 42, No. 1, (2001), pp.110-113.

[8] 瀨戸英俊・森多雄司・姜錫・青木由直：“画像圧縮における フレネル変換を用いたカラー画像電子透かし法,”信学技報, (2000), pp.43-48.

[9] 新井 康平・瀬戸 要: “固有值開に上る情報の偏りを利用し た多重解像度解析に基づくデータ・八イディング," 可視化倩 報学会.

[10] 新井 康平・瀬戸 要 : “ウェーブレット多重解像度解析に基づ くデータ・ハイディング,"第 30 回 可視化情報シンポジウム 講演論文集, (2002).

[11] 新井 康平・瀨戸 要：“スキャン方式を考慮した双直交ウエー ブレット多重解像度解析に基づくデータ・ハイディング," 日本 リモートセンシング学会第 35 回 学術講演会論文集, (2003).

[12] 新井 康平・頼戸 要：“主成分分析に基づく情報ハイディング 手法," 日本りモートセンシング学会 第 37 回 学術講演会諭 文集, (2004).

[13] 新井康平: ウェーブレット解析の基礎理論、森北出版、(2000). 